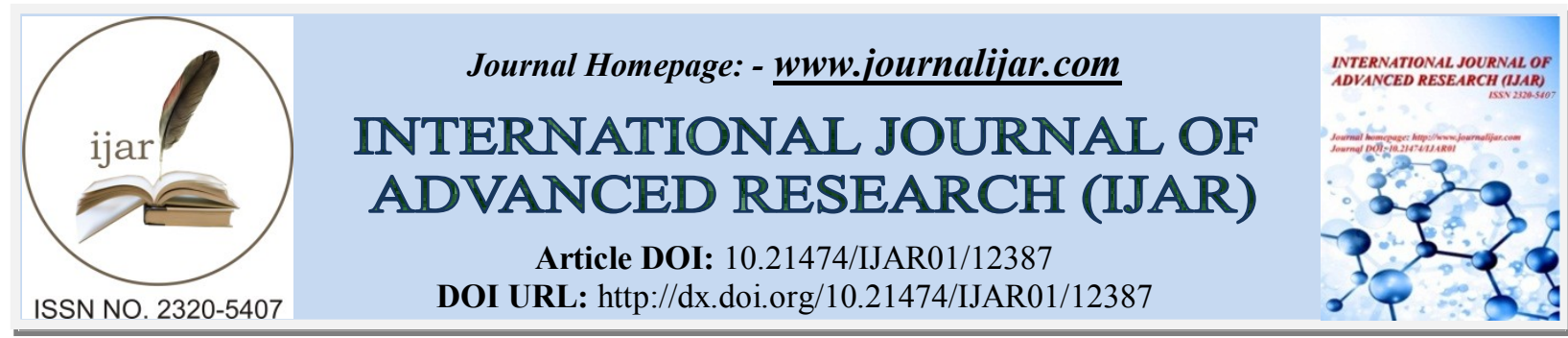

RESEARCH ARTICLE

\title{
SYNERGITY OF HEALTH SERVICES ON SOCIAL ATTITUDES OF HEALTHY LIVING COMMUNITIES IN SOUTH SULAWESI, INDONESIA
}

Dr. Rasidin Calundu Mkes and Dr. Andi Tenriningsih M.pd

Al Ghasali High School Lecturer, Pare Pare. South Sulawesi, Indonesia.

\section{Manuscript Info}

(.........................

Manuscript History

Received: 27 November 2020

Final Accepted: 30 December 2020

Published: January 2021

Key words:-

Healthy, Synergity, Community, P, Social Behavior

\section{Abstract}

Types of qualitative research through the phenomenological approach, the results showed that the health services conducted to date are not yet effective, this is due to the level of consciousness of society has not realized the importance of value healthy life, meaning many people think when sick there is a doctor, there is a hospital, it needs to get attention and cooperation from all stakeholders, academics, community leaders, related officials. Communities are expected to have a pmahaman related to the health and effects posed by.

Copy Right, IJAR, 2021,. All rights reserved.

\section{Introduction:-}

Health is one necessity of life that is very important in supporting daily activities. People make various efforts to realize a healthy life. It holds article 47 in the form of activities with promotive, preventive, curative, and rehabilitative approaches that are implemented in an integrated, thorough, and sustainable manner. Promotive Health Services is an activity or a series of health service activities that are more prioritizing activities that are promotional activities.

Health services are essentially aimed at the prevention and treatment of diseases, including medical services carried out based on individual relationships between physicians and patients needing healing. In the relationship between the physician and the patient, there is a therapeutic transaction meaning that each party has its rights and obligations. Doctors must provide appropriate medical services for patients. This media service can be properly straightening under the procedures, administering the therapy, conducting medical actions according to the standards of medical services, and providing reasonable actions necessary for the healing of patients. The maximum effort that this doctor has to do is to obtain the right he intended from the transaction, which is healing or recovery of his health.

Health services are the fundamental right of society that must be fulfilled in health development. Many health problems in Indonesia are about health care.

\section{Problems:}

1. How health services to healthy living attitudes of people in South Sulawesi?

Library overview:

Public administration:

In the past, administrative sciences were seen as the normative science that emphasized "what should be", but the current developments, the view was demystification, and experts saw the administration as the opalescence 
combining the question "what should be" with "what is" in the question's form "what is probable" so further; moeljarto in marlon (2009).

The public administration of each country has several certain features "how things Are Done", which differs from country to country. In addition, in every administration there are many institutions with their own distinctive characteristics: local, provincial or regional, national and even transnational institutions (in Dr. Enrique Claver, Dr. Juan Llopis and Dr. José L. Gascó, 2000). Most public administration theories (Frederickson 1997; Perry and Wise 1990 in Wouter Vandenabeele, 2007) identify such behaviour as self-sacrifice in realizing the public interest and altruism as the specificity of civil servants and very difficult to explain the behaviour in terms of Rational Choice (Wouter Vandenabeele, 2007).

The proper role of society in public administration has been an active and ongoing area of investigation, experimentation, revolution, and controversy since the birth of this nation. Contemporary movements to test the role of society in making administrative decisions have come in response to problems in the second half of this century and because of concerns by citizens, administrators, and Politicians are more on the desperation of citizens and apathy (Box, 1996; Putnam, 1995, Timnev, 1996; Thomas, 1995 in Cheryl Simrell King, Kathryn M. Feltey and Bridget O'Neill Susel, 1998). Because both things citizens and their leaders have realized, "participation through normal institutional channels has little to no effect on the government's political substance" (Crosby, Kelly, and Schaefer, 1986 in Cheryl Simrell King, Kathryn M. Feltey and Bridget O’Neill Susel, 1998). Many residents, administrators, and politicians are interested in increasing the decision of public participation in society. Attempts to do so are underway throughout the country (Cheryl Simrell King, Kathryn M. Feltey and Bridget O'Neill Susel, 1998).

Administration as an art because in implementing it using skills that reflect individual abilities, as stated by Siagian that the administration is other than as the artistic science and Scientific art. Administration requires ethics in serving the interests of society. As Plato's in Irawati (2007) says that One cannot be a good public demonstrators thou being first a philosopher.

Bellone (Irawati, 2007) argues that the discipline of public administration is predicated on the study of organization. Organizational theory, hypotheses about human behaviour in complex governmental organizations and administrative theories and hypotheses about human behaviour in the Working Group, are fundamental to the theory of public administration. We can explain that public administration talks about human behaviour in government organizations. Even Shafritz and Russell (2005:5) in Irawati, 2007) posited; It is easy to define administration if you are content with being simplistic: it is Government in action - the management of public affairs on implementing public policies.

The verdict on the existence of public administration as part of this political science is also supported by Allen Schick who believes that public administration is devoted to power and has full power to do Devotion to assist the ruler in ruling more efficiently (Thoha, 2002:33 in Anwaruddin, 2004).

This kind of thought was primarily put forward by Dwight Waldo (1953) (Anwaruddin, 2004) who gave a sense of public administration, that "Public administration is the organization and management of men and materials to achieve the purpose of government".

\section{Service:}

According to Munir in Hendra Hadiwijaya (2011:224) service is an activity that a person or group of people with the foundation of material factors through certain systems, procedures and methods to fulfill the needs of others according to Right. This explains that service is the system, certain procedures or methods given to other participants in this case customers so it can fulfil the needs of these customers under with their expectations.

Friendly and professional service has become a condition the organizers of the State administration must fulfil that (Waworuntu in Suratno, S.Ag., MAP, 2013). Siagian in Hasma Erpianti H (2009:9) they often interpret expressed service as a caring activity, preparing something either in the form of goods or services to the users (stakeholders), customers (users) and consumers. They also expect it that both the climate service in the working unit, the customer's assessment of the better of the employees will the quality of service (i.e., performing employees). Finally, customers will be more loyal to the organization when they assess the performance of more positive 
employees (Marisa Salanova and Sonia Agut, 2005). Empirical evidence suggests that, with employees able to provide high-quality services as far as employees can, customers are more valuable to test the benefits of the service, satisfaction, and improve the purchase of their future visitation (for example, Borucki \&Burke, 1999; Bowen, Siehl, \& Schneider, in Hui Liao and Achia Chuang: 2004). According to Munir in Hendra Hadiwijaya (2011) Service is an activity that a person or group of people with the foundation of material factors through certain systems, procedures and methods to fulfill the needs of others under their rights. This explains that service is the system, certain procedures or methods given to other participants in this case customers so it can fulfil the needs of these customers under their expectations.

Tjiptono (1998) in Hendra Hadiwijaya (2011) expressed the quality of service/service is the level of excellence to meet the wishes of customers. In that opinion a quality of service or as an advantage-given the company to fulfill the wishes of customers. Meanwhile, according to Siagian (1998) in Hendra Hadiwijaya (2011) service is a sense of fun that is given to others along with facilities and meet all their needs.

Thus, the service is an effort to provide pleasure to customers, with the convenience of the customers fulfilling their needs. Payne (2000) in Hendra Hadiwijaya (2011) expressed the quality of services relating to the ability of an organization to meet or exceed customer expectations.

Friendly and professional service has become a condition the organizers of the State administration must fulfil that (Waworuntu in Suratno, S.Ag., MAP, 2013). According to Munir in Hendra Hadiwijaya (2011:224) service is an activity that a person or group of people with the foundation of material factors through certain systems, procedures and methods to fulfill the needs of others under their rights.

Siagian in Hasma Erpianti H (2009:9) we often interpret expressed service as a caring activity, preparing something either in the form of goods or services to the users (stakeholders), customers (users) and consumers.

\section{Public Policy:}

The public policy process, at least, includes: 1) formulation of problems; 2) forecasting; 3) Recommendation; 4) monitoring; 5) evaluation. Innovative public policies must always be: 1) based on the public interest; 2) planning, implementation, and supervision, and evaluation involving public participation; 3) The housing is constantly moving dynamically according to the development of public aspirations.

Michael E. Porter in Susy Susilawati (2007) explained that the competitive advantage of each country is determined by how capable the country can create an environment that grows the competitiveness of every actor in it. In global competition, the public sector is to build an environment that allows every development perpetrator to develop themselves into competitive actors.

Thomas R. Dye defines that "Public policy is whatever government did or not. To do "(Whatever the government has done or not done). From this definition, the public policy covers everything that is stated and done or not done by the government. In addition, public policy is also the policies developed/made by agencies and government officials.

In this case the public obstetric theory that the author used was a public obstetric theory according to Thomas R. Dye stating that public policies were what the government did and what the government did not do.

One of the important things related to public policy is creating a public policy. According to Thomas R. Dye Public Policy-making process is a political process involving various interests and resources so that the end of the political process is a subjective product created by the conscious choices of policy actors.

\section{Research Methods:-}

Types of qualitative research through the phenomenological approach

\section{Discussion:-}

Good health care is a necessity for everyone. Everybody wants to feel appreciated, want to be served, and want to get the same position in the eyes of society. However, there are often dichotomies in health care services in 
Indonesia. There have been many cases describing how his medical services face in the country. It is as if it reserves good health services for those with thick wallets. While underprivileged people are not getting the fair and proportional treatment. Poor people don't seem to be sick.

It is not understandable what makes a gap between the rich and the poor in the domain of healthcare services. Doctors in various hospitals often show their identity to the patient implicitly. That going through medical education is not cheap. Therefore, as the fruit of the expensive education that must be pursued, the community must pay the meaning of healthy life with the extraordinary nominal. Perhaps the early paradigm when someone chooses his way of life as a doctor an experience disorientation. Devotion to society and the nation is not a factor that dominates one's desire to be a physician. There are commercialization factors that sometimes lubricated a person in medicine as a choice. A doctor is a position that makes one better appreciate life. The substance is today's overview of a doctor who took place in Indonesia is a commercialization of the work of health ministers. If the paradigm that experienced the disorientation can be straightened then the position of a doctor will return to a glorious level

Health services seem to be often not comparable to the expensive costs incurred. Hospitals sometimes do not serve patients well and are friendly. Doctors sometimes do a diagnosis that tends to random. Not to mention the nurse in the hospital is often lazy if it works. One has said that hospitals in Japan do not provide entertainment facilities such as television for hospital employees. Thus working conditions will be much more conducive because the concentration will not split between work and entertainment affairs. While in Indonesia the existence of television for hospital employees is an inevitor. Actually, this condition can damage the productivity of work. Although there is always justification that professionalism is always held high in the profession. It is unclear of the discourse, but apparently looking at the condition of the hospital in Indonesia with its service, the discourse has a point regardless of the conditions in the hospital in Japan.

\section{Factors affecting health:}

"Health is not everything but without health everything is nothing" means "wellness is not everything but it doesn't matter everything". According to Henrik L. Blumm, there are 4 factors that affect public health, namely: behavioral factors, environment, heredity and health care.

\section{Genetic factors:}

This factor is the least impact an individual or community health compared to other factors. Its influence on individual health status is evolutive and the most difficult detection. For that need genetic counseling. For the sake of public or family health, genetic factors need attention in the prevention of disease.

For example, a child born to a diabetes of elderly people will have a higher risk than a child born from a person who is not a DM patient. For preventive efforts, children born from DM sufferers must be notified and always beware of genetic factors inherited by their parents. Therefore, he had to regulate his diet, regular exercise and other preventive efforts so that no chance of genetic factors evolved into a risk factor in the occurrence of DM on him. So it can be comparable, genetic is a bullet (bullet) human body is a pistol (weapon), and the environment/human is the trigger (trigger). The greater the population that has the risk of congenital diseases will increasingly difficult efforts to increase health degree. Therefore, there is a need for the good marriage counseling to avoid congenital diseases that can be prevented in the emergence. Lately, health and medical technologies have been advancing. Technology and expert skills should be directed to increase the effort to realize the degree of highest health.

\section{Community behaviour factor:}

Behavior is a good human activity that can be observed directly or not. Behavior is the result of all sorts of human and environmental experiences and interactions (central MFI MoH RI, 1992)

This factor is particularly in developing countries most likely to influence health disorders or health problems in the community. The availability of health services (health service) without the change of behavior (participation) of the community will cause health problems remain potential growth in the community. For example, provision of facilities and immunizations will not be of much benefit when mothers do not come to immunization posts. The behavior of mothers who do not utilize the health care that has been available is due to lack of knowledge of mothers about the benefits of immunization and side effects. The knowledge of mothers will increase because of health counseling about immunisation provided by health workers. 
Behavior of individuals or groups of unhealthy society will also affect environmental factors that facilitate the onset of disease. Healthy behavior will support the increasing degree of health, this can be seen from the many behaviors based diseases and lifestyles. Healthy diet habits can prevent us from many diseases, including heart disease, high blood, stroke, obesity, diabetes mellitus and others. The behavior/habit of washing your hands before eating can also prevent us from gastrointestinal diseases such as diarrhea and others. More operational behavior can be interpreted as a person's response to the outside stimulus, and the response is divided into 2, namely:

\section{Passive form response:}

Passive forms are internal responses, which are occurring in humans and not directly observable by others. This passive form of response is a thought, a response or an inner attitude, and a knowledge. For example, a mother knows that immunization is useful to prevent the iaponicae of certain diseases, but it never takes her son to Posyandu or to the Puskesmas for immunization. Such behavior is still disguised (covert behaviour).

\section{Response form active:}

An aktiv response means that the behavior can be directly seen or observed. For example, the mother who already knows the benefits of immunization to the health of her child, will bring her child to Posyandu or puskesmas for immunization. This behavior is already real (overt behaviour). Health behaviour is nothing but a reaction of a person to stimuli related to illness and disease, health service systems, food and the environment. This reaction can be passive in form and can also be active.

\section{Environmental factors:}

Environments that support clean lifestyles also play a role in increasing health. In life around us we can feel, the slums and not treated are usually many inhabitants who suffer from diseases such as: itching, respiratory tract infections, and infections of the gastrointestinal tract. Environmental factors also influence dengue fever disease. The environment is not clean, the number of water shelters that have never been cleaned cause the development of Aedes aegypti mosquitoes caused the increased dengue fever (Maskoeri, Jasin. 1994).

This causes the population of the surrounding people to have a risk of mosquitoes and infected with dengue fever. To analyse the field health programs, the H.L. Blum paradigm can identify and classify problems under the factors hat affect public health status.

Analysis of the 4 factors should be done carefully so that problems kesmas and problems of the program can be clearly planned. This analysis of the 4 factors is part of the analysis of the situation (part of the function of the contemplation) for the development of health programs in a particular region. Included in this environment are:

\section{Improved public health:}

Healthcare personnel must be able to invite, motivate and empower the community, able to involve cross-sectoral cooperation, able to manage efficient and effective health service system, able to become the leader, pioneer, coaching and exemplary life Healthy. Community empowerment in the development and empowerment of the very important community is how to invite and excite people to be interested and responsible for their own health by mobilizing the source of the existing funds on them.

Health and political commitments health problems are essentially a political issue to solve the health problems of political commitment. Nowadays, there is still an assumption that the element of population health does not much role in socio-economic development. Policy determinants Many think the health sector is a more consumptive sector than the productive sector as a qualified human resources provider, so that when there is a shock in the state economic allocation to Sector will not increase.

Organizing existing health efforts, existing healthcare facilities are a vehicle and a support facility from the maintenance of health services oriented to the efforts of healing the disease, then to support the implementation A healthy paradigm oriented towards proactive promotive-preventive efforts, community centered, active participation and community empowerment, all energy rides and facilities now need to be made adjustments or even reforms including Reform of activities and programmes in health education centers. 
The challenge for the upcoming government is how to continue to improve the state of health while restructuring and reforming the health system in this decentralized era. The most important task is to provide more attention to key health conditions, improve the feasibility of health conditions and the utilization of health systems, involving private roles, re-testing the health financing mechanisms and implementing decentralization, and health workers.

1. To focus on improving the main health condition and management of the comprehensive health system.

Although Indonesia is undergoing an epidemiological transition, funding of healthcare services provided through government budgets should remain focused on several important diseases, namely in the pattern of infectious diseases that still dominate. Changing the focus of health policy to some of the most important infectious diseases while controlling the emergence of new infectious diseases (NCD) is a challenge.

\section{The largest in the new health system.}

Concentrate the use of public funds on the provision of public health and improve the feasibility of priority health conditions.

Government health financing in Indonesia is lower compared to most neighboring countries. Therefore prioritizing this limited government budget for the provision of public health (such as immunization and treatment/to control infectious diseases) becomes very important to ensure the control and management of the healthcare sector thoroughly. It is also important to encourage and ensure the quality of healthcare services and to provide several healthcare services where the market is incapable of providing it (such as education and health information). Meanwhile, the provision of health facilities is a second priority, except in areas where there is a failure of market mechanisms, such as the private sector can not afford or do not want to provide several health services. Nevertheless, governments can involve the private sector to provide several specific services, as long as they can provide it more efficiently.

These functions can be done by local governments, while the central government can do three important things to encourage the distribution of more pro-poor funds namely by: (i) making the DAU distribution fairer by strengthening the formula-based allocation mechanism, which incorporates the element of human development index, under the latest revision of LAW 25/1999; (ii) to enlarge the DAK for health, focus on providing basic health services, especially for poor districts; (iii) Empowering the poor through the provision of third-party healthcare financing, providing health information and giving them greater control over several healthcare providers.

\section{Health services and social behavior of public health :}

Public health services from the government is still less maximum alias less satisfactory. We can see it from the Ministry of government-owned hospitals that prefer the payment/settlement of the new administration of the first patient can be handled medically so for the underprivileged community who need to get medical treatment/treatment should wait for a queue long enough. Because of the consideration of costly costs and poor service so that our community ignores the healing process of diseases such as drugs from prescription doctors are not purchased fully even some of them more entrust the cure of diseases to the more trusted people by visiting "smart people/shamans" and go to the religious experts who do not have medical educational background. They came back to the hospital when the disease had been chronic/hard to cure.

Other things for middle-and upper society and officials, their behavior more trusting in the service and treatment of overseas diseases such as to Singapore, Malaysia to Japan to get health services and they believe can heal when treating overseas.

The seriousness of the government in healthcare through a government-owned hospital is far from what the community expects, including from providing services such as the responsiveness, willingness, readiness and speed of the officer in delivering service to the competence of its medical officers, resulting in malpractice to the patient. Lack of health infrastructure that is still considered expensive by the Government hospital so that people do not get health services that impact the patient's not complete.

Government Program in the form of BPJS is considered by the public is not wholeheartedly done by the government ranging from the bureaucracy of the service of BPJS patients in clinics, health centers to hospitals. The government is responsible, the lack of service BPJS because of the cheap contribution of BPJS that is borne by the community, 
but the impact of the poor health services resulted in the number of people who are lazy to have a cure to the doctor until complete/cured.

Government focus to know of is to control the price of the drug so as not to burden the patient, facilities and infrastructure of the hospital is more enhanced by not charging the patient (control costs, checks up, transfusion etc.) And is the government should intervene to give an upper limit tariff for the services of doctors to be not expensive.

\section{Conclusion:-}

health services conducted by the Government until now not effective, this is due to the reality in the field that the society has not realized the importance of healthy lifestyle, meaning that many people think when sick there is a doctor, there is a hospital, this needs to get attention and cooperation from all stakeholders, academics, community leaders, officials related. Community is expected to have an understanding related to the health and effects posed.

\section{Bibliography:-}

1. Azwar, Azrul.1996.Pengantar Administrasi Kesehahatan Edisi Ketiga.Tangerang : Binapura Aksara.

2. Elmi, Bachrul. 2002. Finance of autonomous regional governments in Indonesia. Jakarta: UI-Press.

3. Koentjoro, Tjahjono. 2007. Health regulation in Indonesia. C. V Andi Offset. Yogyakarta.

4. Maskoeri, Jasin. 1994. Basic natural Sciences. Jakarta: PT Raja Gafindo Persada.

5. Mubarak, Ikbal, Wahid, SKM and Chayatin, Nurul. 2009. Public health Sciences. Salemba Medika: Jakarta

6. Notoatmodjo, Soekidjo. 2003. Public health Sciences (Basic Principles). Jakarta: PT. ASDI Mahasatya.

7. TIM IAD MKU UMS, TEAM MUP. 2008. Basic knowledge. Surakarta: Muhammadiyah University Press.

8. Utami, Sri Tjahyani Budi, 2003. Air and healthcare eye pollution module. Depok: FKM-UI.

9. Ali, Zaidin (2000) Introduction to Nursing service in Puskesmas; 6 Series Public health care, Depok

10. Azwar, Azrul. 1996. Introduction to the Health Administration of the third edition. Tangerang: Binapura Aksara.

11. Depkes RI (1987) community participation, education and training Center for employees, Jakarta

12. Effendi, Nasrul (1998) Public health Fundamentals, Ed. 2, EGC, Jakarta

13. Koentjoro, Tjahjono. 2007. Health regulation in Indonesia. C. V Andi Offset. Yogyakarta.

14. Mubarak, Ikbal, Wahid, SKM and Chayatin, Nurul. 2009. Public health Sciences. Salemba Medika: Jakarta

15. Notoatmodjo, Soekidjo. 2003. Public health Sciences (Basic Principles). Jakarta: PT. ASDI Mahasatya.

16. Poerwanto, Helena and Syaifullah. Labor law in health and safety. Jakarta: Faculty of Law of the University of Indonesia, 2005. Indonesian.

17. Ryadi Slamet (1982) Public Health Sciences; The fundamentals and History of Development, Ed. Revised, national business, Surabaya.

18. Silalahi, Bennett P.S. [and] Silalahi, Rumondang. 1991. Occupational safety and health management. [S. 1]:P Ustaka Binaman Pressindo.

19. Suma'mur. 1985. Occupational safety and accident prevention. Jakarta: Mount Agung, 1985

20. Law No. 1 year 1970 on Occupational safety Indonesia.

21. Law No. 3 of 1992 on Social Security of Labour.

22. Arja Sadjiarto (2000), "Akuntabilitas dan Pengukuran Kinerja Pemerintahan", Jurnal Akuntansi \& Keuangan Vol. 2, No. 2, Nopember 2000.

23. Bambang Sancoko (2010), "Pengaruh Remunerasi terhadap Kualitas Pelayanan Publik", Bisnis \& Birokrasi, Jurnal Ilmu Administrasi dan Organisasi, Vol. 17, No. 1, Jan-Apr 2010.

24. Chairun Nasirin (2013), "Reformasi Administrasi Publik: Sebuah Kajian Konseptual", Jurnal Ilmiah Administrasi Publik dan Pembangunan, Vol.4, No.2, Juli-Desember 2013.

25. Celine Santoso (2013), "Teori Administrasi Publik", http://blog.ub.ac.id/celineshanlight/2013/02/21/teoriadministrasi-publik/

26. Dyah Hariani (2008), "Manajemen Komplain dan Penanganan Keluhan Dalam Pelayanan Publik", Jurnal Ilmu Administrasi Dan Kebijakan Publik "Dialogue" JIAKP, Vol. 5, No. 2, Mei 2008.

27. Endang Larasati (2008), "Reformasi Pelayanan Publik (Public ServicesReform) dan Partisipasi Publik", Jurnal Ilmu Administrasi Dan Kebijakan Publik "Dialogue” JIAKP, Vol. 5, No. 2, Mei 2008.

28. Elvira Zeyn (2011), "The influence of good governance and the government accounting standards for financial accountability with the commitment of the Organization as a moderate", accounting and accountancy reviews of ISSN: 2088-0685 Vol. 1 No. 1, April 2011. 
29. Ferry Roen (2011), "Transaction Cost Theory", http://perilakuorganisasi.com/theori-biaya-transaksi-transactioncost-theory.html.

30. Felicia Goenawan (2007), "Political Economy of advertising in Indonesia against the concept of Beauty", scientific journal SCRIPTURA ISSN 1411-XXXX Vol. 1 No. 1 January 2007. Habsul Nurhadi (2013), "Ekonomi Politik Baru : Dari Pengertian Sampai Contoh Empirik Pembangunan", http://ekonomi.kompasiana.com/manajemen/2013/11/12/ekonomi-politik-baru-dari-pengertian-sampai-contohempirik-pembangunan-608766.html.

31. Hendrikus Triwibawanto Gedeona (2007), "Akuntabilitas Kelembagaan Eksekutif”, Jurnal Ilmu Administrasi Volume 4 No 1 Maret 2007.

32. Heryanto Monoarfa (2010), "Efektivitas dan Efisiensi Penyelenggaraan Pelayanan Publik: Suatu Tinjauan Kinerja Lembaga Pemerintahan", Naskah Publikasi 2010.

33. Irawati (2007), "Pembaruan Administrasi Dan Birokrasi (Sebuah Era Perubahan)", Jurnal Madani Edisi I/Mei 2007.

34. Luluk http://candupendidikan.wordpress.com/2012/06/03/dasar-dasar-perilaku-individual/

35. Reynaldi Riantiarno \& Nur Azlina Pekbis (2011), "Faktor-Faktor Yang Mempengaruhi AkuntabilitasKinerja Instansi Pemerintah(Studi pada Satuan Kerja Perangkat Daerah Kabupaten Rokan Hulu)", Jurnal, Vol.3, No.3, November 2011.

36. Sad Dian Utomo (2008), "Penanganan Pengaduan MasyarakatMengenai Pelayanan Publik Bisnis \& Birokrasi", Jurnal Ilmu Administrasi dan Organisasi, Vol. 15, No. 3, Sept—Des 2008.

37. Teni Listiani (2007) "Implementasi Kebijakan Transparansidan Akuntabilitas Pelayanan Publik(Studi di PDAM Kota Bandung)", Jurnal Ilmu Administrasi Volume IV No. 3 September 2007.

38. Teguh Kurniawan (2009), "Peranan Akuntabilitas Publik dan Partisipasi Masyarakatdalam Pemberantasan Korupsi di Pemerintahan", Bisnis \& Birokrasi, Jurnal Ilmu Administrasi dan Organisasi, Mei-Agustus 2009, hlm. 116-121 Volume 16, Nomor 2 ISSN 0854-3844. 